\title{
Design of Automatic Transfer Switch ACOS with Human Machine Interface Monitoring System in Shipboard Application
}

\author{
Sardono Sarwito ${ }^{1}$, Indra Ranu Kusuma ${ }^{2}$, Boy Hendra Waramory ${ }^{3}$
}

\begin{abstract}
ACOS with PLC system. The supply of electricity will move from the main generator to the battery when the main generator lost one phase, and the power supply will switch to the emergency generator when the voltage in accordance with the emergency generator working voltage AC electrical equipment on board is 380VAC. Electricity supply shall not move directly from the emergency generator to the main generator but to the battery first to prevent damage to the AC electrical equipment on board. Transport time for the system for 30 seconds ACOS equipment in accordance with the ICC and SOLAS regulations which require the transfer of under 45 seconds. ACOS equipment can be used in real conditions on the ship because it has phase failure, under voltage and over voltage protection and a relay as an indication for the transfer of command power supply automatically.
\end{abstract}

Keywords - PLC system, ACOS equipment.

\section{INTRODUCTION}

B lack out condition at shipboard is a condition that main generator cannot supply the electricity to the consumer due to emergency condition. This emergency caused the ship crew cannot operate the main generator. In this condition, emergency generator should be activated. This ACOS have capability to switch electrical energy from main source to emergency source and to increase the value of safety, this system activated automatically so that the ship is not in a state of black out in a long time [1-2]. It turns on the emergency generator during an outage, monitor the operating conditions of the generator to normal and ready to supply power, to move the switch main burden of power source around the generator to an emergency generator or vice versa, and turn off the emergency generator when the power source play generator is back supplying power in ship [1-3].

\section{A. Component Equipment of Automatic Change Over Switch (Acos)}

ACOS system has several circuit system consisting of a series of power and control circuit or control circuit. The series aims to provide a power supply or distribute electricity from the main generator, the battery and the emergency generator to the electrical load. The whole process is a centralized control system on PLC receiving instructions or orders either from the HMI or voltage and phase detection sensor failure.

Equipment that used for the ACOS system are :

- MCB 1 Phase (2A, 24A)

- PLC (Omron CPM1A CDR30-V-1)

- Phasa Failure Relay (380V, 3 phasa)

Sardono Sarwito is with Department of Marine Engineering, Institut Teknologi Sepuluh Nopember, Surabaya 60111, Indonesia. E-mail: sarsar@its.ac.id

Indra Ranu Kusuma is with Department of Marine Engineering, Institut Teknologi Sepuluh Nopember, Surabaya 60111, Indonesia. Email: kusuma@its.ac.id

Boy Hendra Waramory is with Department of Marine Engineering, Institut Teknologi Sepuluh Nopember, Surabaya 60111, Indonesia.
- Relay AC (220VAC, 10A)

- MCB 3 Phase (6A)

- Power Supply (220VAC, 24VDC)

- Contactor AC $(2.2,2.7,4 \mathrm{KW})$

- Relay DC (24VDC, 10A)

- Noise Filter (220VAC)

- Over\&Under Voltage Relay (380V, 3 Phasa)

Equipment ACOS (Automatic Change Over Switch) is made according to the rules and regulations [4-5]. This equipment uses 10 pieces of light as a simulation of emergency load the battery. This equipment uses a dc lamp as emergency electrical load which will be supplied by a battery with a capacity of $12 \mathrm{v}, 7 \mathrm{a}$. Specifications emergency equipment components used are as follows:

- 10 lamps with a voltage of $12 \mathrm{~V}$, and power $5 \mathrm{~W}$

- MCB (Miniature Circuit Breaker) 12x2 mm

- Busbar 10A, 125A

\section{B. Acos System Circuit}

The power circuit in the equipment is functioning as a liaison or the dealer system from the main power to the load generator and emergency generator to the load.

The series of inputs and outputs on the device is used as a signal for the PLC decision makers to execute a command. Input served as an indication for the main generator and an emergency generator output while serving as acting out of work to load the PLC program. Input used on this equipment as much as 5 pieces, and the output of 5 pieces. Table 1 is a table of input and output PLC. 


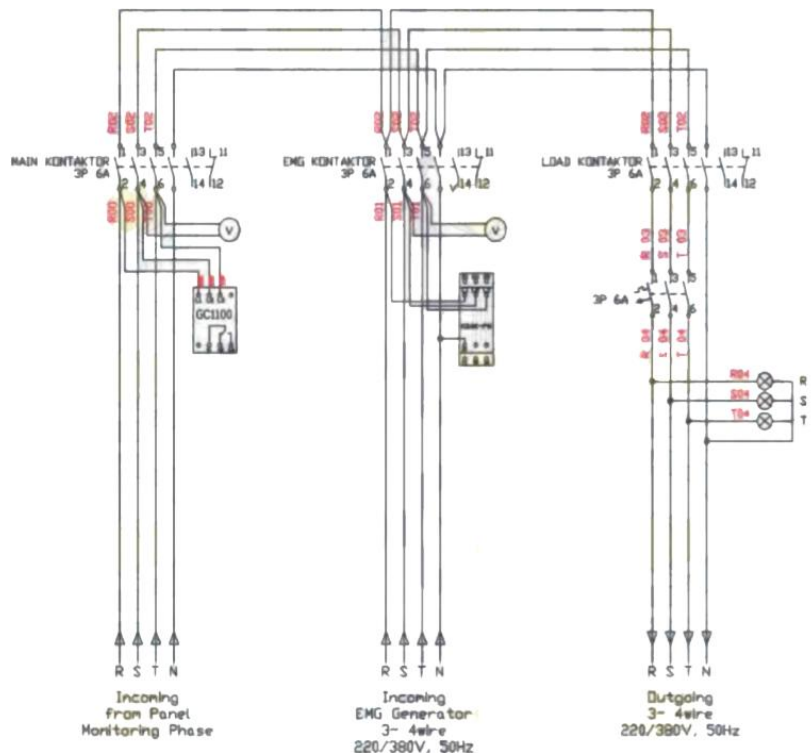

Figure. 1. Wiring Diagram Power ACOS

TABLE 1

INPUT PLC

\begin{tabular}{|c|c|c|}
\hline No & $\begin{array}{c}\text { Address } \\
\text { Input }\end{array}$ & Description \\
\hline 1 & 0.00 & RCP main generator \\
\hline 2 & 0.01 & RCU emergency generator (under voltage) \\
\hline 3 & 0.02 & Push button emergency \\
\hline 4 & 0.03 & RCU emergency generator (over voltage) \\
\hline 5 & 0.04 & Relay indicator battery \\
\hline
\end{tabular}

TABLE 2

OUTPUT PLC

\begin{tabular}{|c|c|c|}
\hline No & $\begin{array}{c}\text { Address } \\
\text { Input }\end{array}$ & Description \\
\hline 1 & 10.00 & Kontaktor main generator \\
\hline 2 & 10.01 & Relay Battery Supply \\
\hline 3 & 10.02 & Relay Emergency generator starting \\
\hline 4 & 10.03 & Kontaktor Load \\
\hline 5 & 10.04 & \multicolumn{2}{c}{} \\
\hline
\end{tabular}




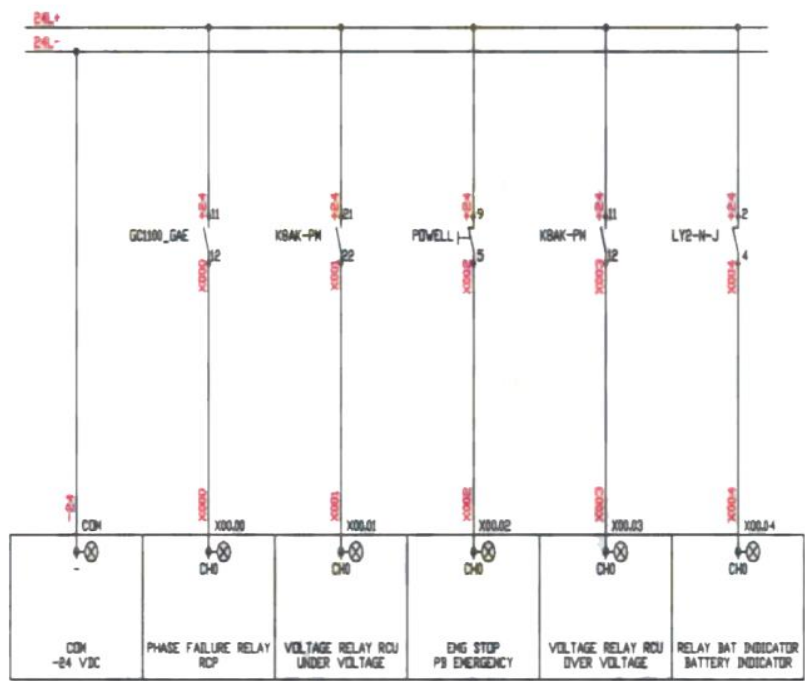

Figure. 2 Wiring Diagram Input PLC

This series of power supply used to provide power or electricity supply to the equipment. The supply of electricity used is AC and DC power supply. AC power supply is used to run the PLC, contactors and relays AC.

While the supply of DC power to run equipment such as DC relays and HMI. Voltage to the AC power used is equal to 220VAC while the voltage to the DC power used is equal to 24VDC. For DC electrical equipment, the applied voltage is equal to $12 \mathrm{VDC}$.

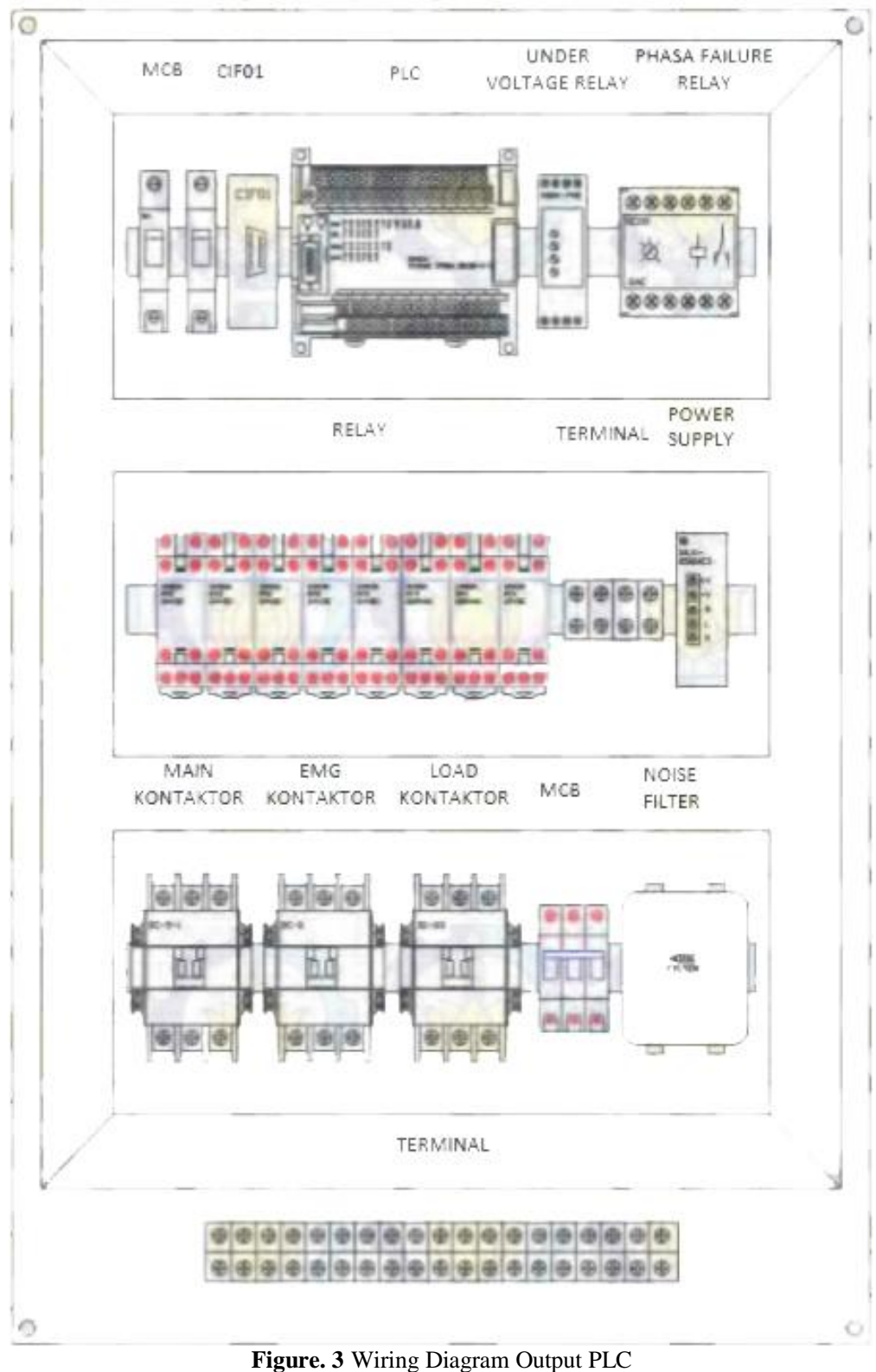

Figure. 3 Wiring Diagram Output PLC 


\section{METHOD}

All the systems will be analyzed based ob 3 conditions that is :

- Condition A. Main generator ready, ready battery, emergency generator ready

- Condition B. Main generator Not Ready, Baterry ready, Emergency generator ready

- Condition C, Baterry ready, Main generator not ready, Emergency generator not ready

\section{RESULTS AND DISCUSSION}

A. Condition A. Main generator ready, ready battery, emergency generator ready

Condition when the initialization process, the ready electricity supply is the main generator, batteries and emergency generators. When the run button on the HMI is pressed, the PLC gives orders to supplay electric power to the load. When RCP off (indication of loss of one phase generator play) the generator will shut down and switch to battery supply. The battery will supply for 5 seconds waiting for equipment supplied by electricity from the main generator actually off and then will switch to an emergency generator. Emergency generator will supply electricity to power equipment such as ship navigation equipment, lighting equipment, and other emergency lighting. When the PLC detects the RCP on (an indication of the main generator is normal), the emergency generator will off and supplied by the battery for 5 seconds to turn off the equipment supplied emergency generator. After 5 seconds, it will switch to supply the main generator.

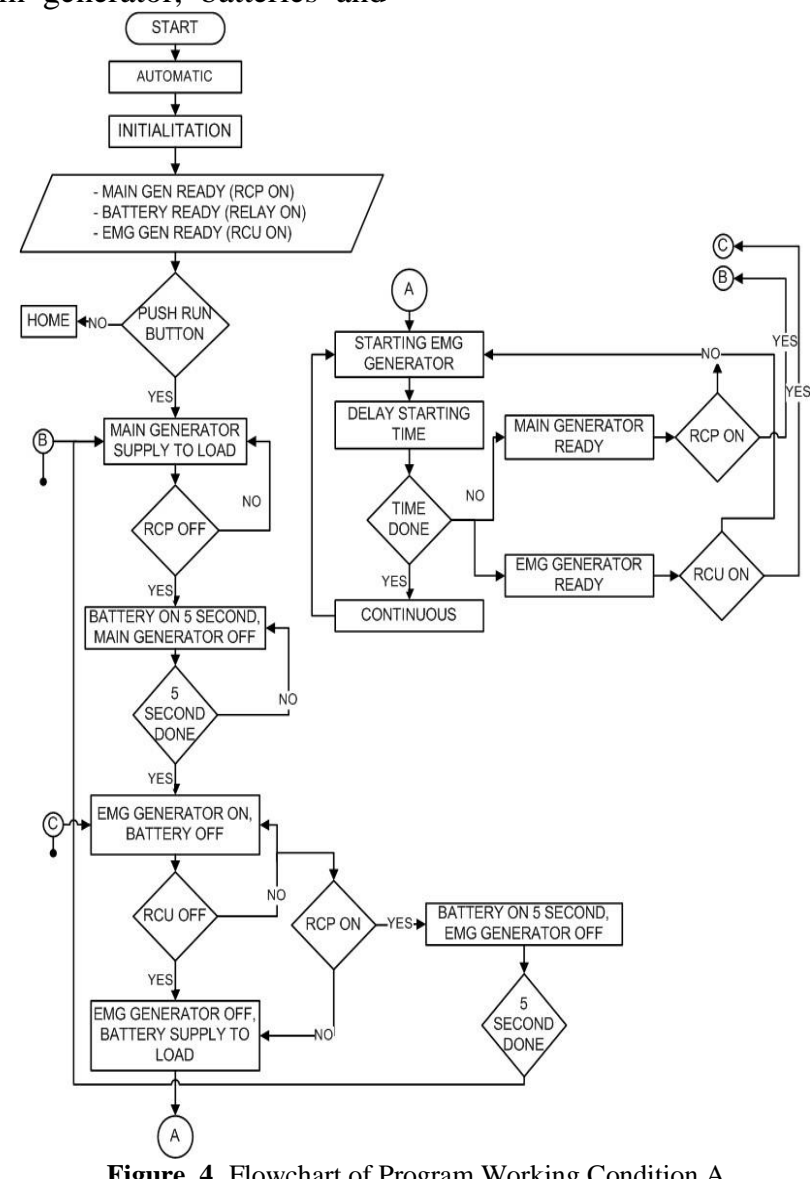

Figure. 4. Flowchart of Program Working Condition A

B. Condition B. Main generator Not Ready, Baterry ready, Emergency generator ready

Initialization process conditions, the ready electricity supply is the emergency generator and batteries. When the RUN button on the HMI is pressed, the PLC commands to emergency generator supplying electricity to the load.when RCU off (indication of loss of one phase of emergency generator on / off), emergency generator will shut down and switch to battery supply. After the RCP on (indication of the main supply generator ready) then the PLC commands to move the power supply to the main generator. If the RCP is not on, the PLC will it signals to the emergency generator to starting. Starting given time for 20 seconds, if within 20 seconds the emergency generator is not on, it will display the command to turn on the emergency generator manually. After turning the emergency generator manually, then the RCU on back (indication that the supply of emergency generators ready) and pressing the "continuous" on the HMI. When the "continuous" is pressed, the power supply will switch to the emergency generator. 


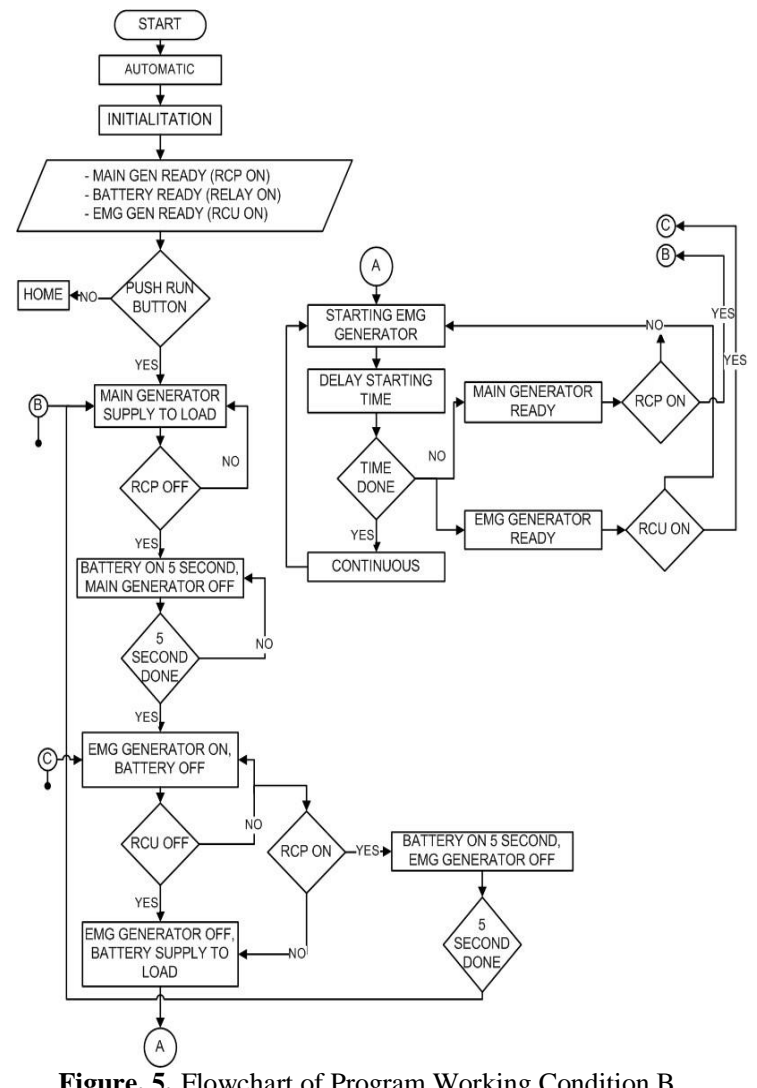

Figure. 5. Flowchart of Program Working Condition B

C. Condition $C$, Baterry ready, Main generator not ready, Emergency generator not ready

Conditions of electricity supply is a battery ready. When the RUN button on the HMI is pressed, the PLC commanded a battery supply power to the DC load. Battery supply power, it is directly PLC sends a signal to the emergency generator to starting. Starting conducted over a period of 20 seconds, when before the 20 seconds expire and emergency generator ready (RCU on), moving the PLC power supply from the battery to the emergency generator.Ketika battery is still supplying electricity to the DC load and RCP on (an indication of the main generator ready), PLC will move the generator to the main electrical supply. When the main generator having problems or loss of one phase (RCP off) then supply electricity directly transfer to battery. Similarly, the emergency generator, when the RCU off (emergency generator phase loss), the supply of electricity will go directly to the battery.

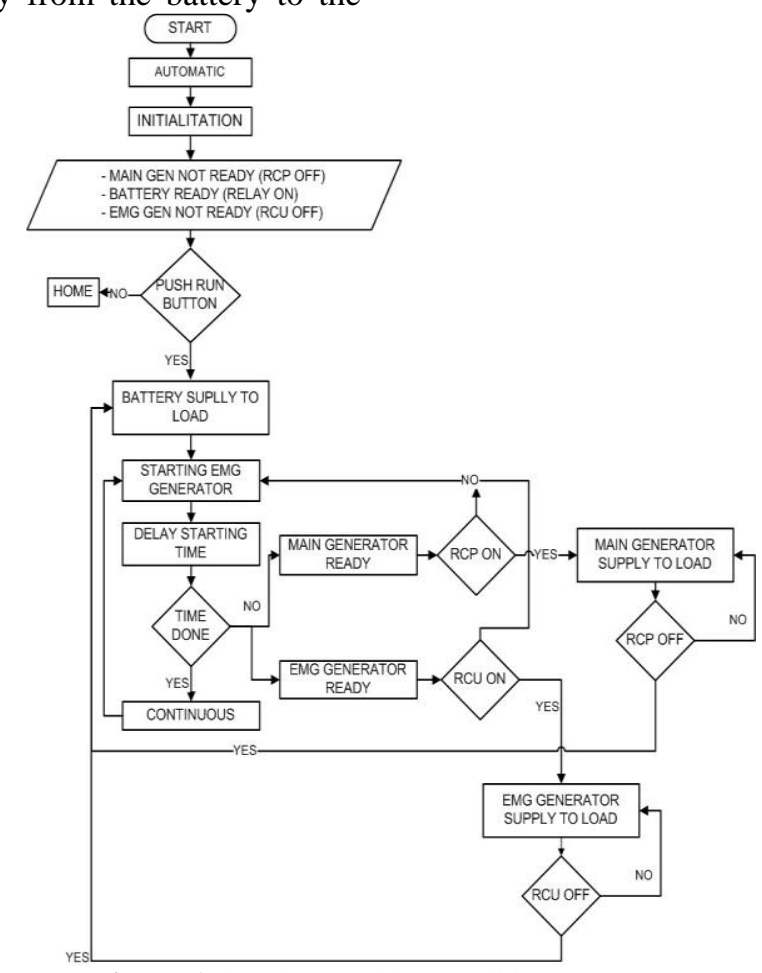

Figure. 6 Flowchart Working Conditions Program C 


\section{CONCLUSION}

From the results of tests performed in this thesis, it can be deduced as follows:

a. Electricity supply will move from the main generator to the battery when the main generator lost one phase and move to the emergency power supply voltage emergency generator when the generator in accordance with a working voltage ac electrical equipment on board is $380 \mathrm{VAC}$.

b. Electricity supply not move directly from the emergency generator to the main generator but to the battery first to prevent damage to the ac electrical equipment on board.

c. Transport time for the system for 30 seconds acos equipment in accordance with the icc and solas regulations which require the transfer of under 45 seconds.

d. There interlock system on the equipment to secure the incoming power supply simultaneously.

e. Equipment acos can be used in real conditions onboard because it has phase failure, under voltage and over voltage protection and an indication of the relay as the electricity supply removal orders automatically.

\section{REFERENCES}

[1] Pandji, Hanung."Perancangan Peralatan Otomatisasi Emergency Baterai Untuk Supplai Daya Listrik Pada Saat Kondisi Blackou Di Kapal". 2011.

[2] Setiawan, Nico Agung."Pengaturan Tekanan Pada Model Instalasi Pengisian BBM Premium di PT. Pertamina Berbasis Programmable Logic Controller". 2005.

[3] Shiha, Muhammad Nur."Rancang Bangun Sistem Automatic Transfer Switch Dan Automatic Main Failure PLN - Genset Berbasis PLC Dilengkapi Dengan Monitoring". 2011.

[4] Teguh, Adriyono,"Pemanfaatan PLC Sebagai Kendali Lengan Robot Dua JAri Pemindah Benda”. 1999.

[5] Yudhiwardana, Nuris Sanggra."Perancangan Perangkat Lunak Programmable Logic Controller Sebagai Pengendali Stabilitas Kapal”. 2009. 